\title{
INVESTMENT FACTOR INFLUENCE ON ECONOMIC DEVELOPMENT OF RAW AREAS IN RUSSIA
}

\author{
Senior lecturer Olga Karpycheva,
}

Assoc. Prof. DSc Irina Filimonenko,

Prof. DSc Zoya Vasilyeva,

Senior lecturer Olga Govorina

Siberian Federal University, Russia

\begin{abstract}
The disparity of economic development between regions of Russia is still under discussion. To date, a range of methods and models for evaluation of regional inequality exist. Russian researchers use statistical indicators (Gini and variation coefficients, Atkinson and Tail indexes) to measure the level of difference between GRP, population income, salary, investment allocation, tax incomes, budget incomes and others. The authors associate the disparity of regional development with the natural and artificial competitive advantages and with institutional factors.
\end{abstract}

The article focuses on the problems and priorities of the prospective development of raw areas in Russia. It contains the analysis of the current level of regional social economic development and key criteria for the selection of regions whose development is significantly determined by the mineral resources availability.

Current economic situation has been worsening due to reduction of raw material mining. The objective is to find the factors useful for developing the economic growth potential not dependent on mining.

Econometric methods were used in the research. At the preliminary stage, structural analysis were conducted, it allows identifying the most important sectors for economic regional development. The technique involves the construction of the equation demonstrating how the total output of the industry depends on several factors: investments in fixed capital, number of workers in industry, wage level, etc. The resulting figure for the region presents the share of each industry contribution into economy (in percent) and the degree of influence of every industry on regional economic development. The results of the research help to determine the degree of dependence of social and economic development of the region on each industry functioning of and impact of different factors on overall resulting indicators for the industry. Further analysis is required to build a model for potential of regional development.

Key words: regional economic development, investment factor, structural analysis, raw areas, disparity of regional development

\section{INTRODUCTION}


Russian economy is known by high level of natural resources specialization. From early $21^{\text {st }}$ century the proportion of raw materials in overall export of the Russian Federation grew steadily and rose to $70,5 \%$ in 2014 . The global economic crisis had a negative effect on mineral industry of Russia. In 2016 the share of mineral resources in overall exports of the Russian Federation decreased by $58 \%$, following the overall decline in mineral extraction in the country (Figure 1) [1].

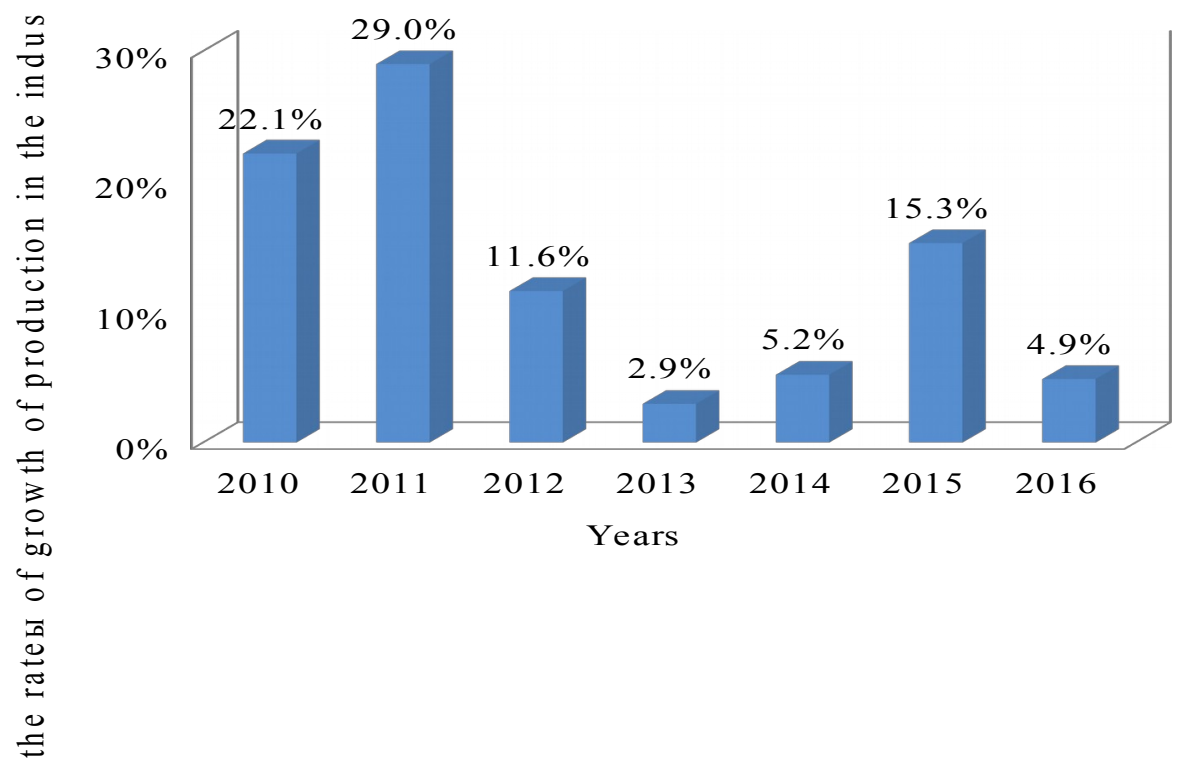

Figure1 - The dynamics of production in the RF mining industry in 2010-2016

Nevertheless, according to the International Energy Agency, Russia remains one of the leaders in production of crude oil, oil products, natural gas and coal (Table 1) [2].

Table 1 - The ranks of Russia in the world mining industry and in export of natural resources in 2015

\begin{tabular}{lcccc}
\hline Natural Resources & $\begin{array}{c}\text { The RF share in } \\
\text { the world } \\
\text { production, } \%\end{array}$ & $\begin{array}{c}\text { The RF rank in } \\
\text { the world } \\
\text { production }\end{array}$ & $\begin{array}{c}\text { The RF share in } \\
\text { the world export, } \\
\%\end{array}$ & $\begin{array}{c}\text { The RF rank in } \\
\text { the world } \\
\text { export }\end{array}$ \\
\hline Crude oil & 12.3 & 3 & 11.2 & 2 \\
\hline Oil products & 7.1 & 3 & 20.9 & 1 \\
\hline Natural gas & 17.8 & 2 & 23.1 & 1 \\
\hline Coal & 4.5 & 6 & 10.8 & 3 \\
\hline
\end{tabular}

Thus, economic development of the Russian Federation is closely dependent on natural resources, being referred to in economic literature as a "Resource curse". The effect of the "Resource curse" is evident in the slowdown of institutional transformations, economic growth decrease and low quality of life of population. Russian economy is still very dependent on the volume of export of oil on European and Asian markets. 
Natural resources are located unevenly across the territory of the Russian Federation. In this paper, to highlight the resource regions, we suggest to compare share of mineral extraction to Gross Regional Product (GRP). The calculation of this indicator will help to identify regions with high natural resources dependency.

Mineral extraction specialization of the Russian economy worsens imbalances in socialeconomic development of the RF regions. In 2016, 20 administrative regions out of 87 generated $91.7 \%$ of all revenue gained from mineral extraction. Resource regions attract investments, well qualified and mobile labor force, which make these regions leaders in terms of GRP (Table 2) [3].

Table 2 - The raw areas of the RF

\begin{tabular}{|c|c|c|c|}
\hline RF regions & $\begin{array}{l}\text { The share of } \\
\text { mining industry } \\
\text { in GRP, \% }\end{array}$ & $\begin{array}{l}\text { per capita GRP } \\
\text { (thousand rubles) }\end{array}$ & $\begin{array}{l}\text { The rank } \\
\text { of the } \\
\text { region in } \\
\text { per capita } \\
\text { GRP }\end{array}$ \\
\hline Nenets Autonomous Okrug & 74.3 & 4252.31 & 1 \\
\hline $\begin{array}{l}\text { Khanty-Mansiysky Autonomous } \\
\text { Okrug }\end{array}$ & 66.9 & 1761.12 & 3 \\
\hline Sakhalin Oblast & 65.7 & 1620.34 & 4 \\
\hline Tyumen Oblast & 54.2 & 1453.08 & 5 \\
\hline Yamalo-Nenets Autonomous Okrug & 50.2 & 2985.47 & 2 \\
\hline The Republic of Sakha & 44.5 & 690.61 & 8 \\
\hline Chukotka Autonomous Okrug & 42.9 & 1119.92 & 6 \\
\hline Orenburg Oblast & 36.0 & 364.77 & 26 \\
\hline The Republic of Komi & 33.6 & 553.86 & 10 \\
\hline Tomsk Oblast & 28.5 & 399.20 & 21 \\
\hline Arkhangelsk Oblast & 26.9 & 454.81 & 15 \\
\hline Udmurt Republic & 24.2 & 291.28 & 44 \\
\hline Kemerovo Oblast & 21.6 & 273.82 & 49 \\
\hline Astrakhan Oblast & 21.5 & 283.59 & 47 \\
\hline Irkutsk Oblast & 19.9 & 375.49 & 24 \\
\hline
\end{tabular}




\begin{tabular}{lccc}
\hline The Republic of Tatarstan & 19.8 & 434.51 & 16 \\
\hline Magadan Oblast & 17.2 & 650.24 & 9 \\
\hline Krasnoyarsk Krai & 16.9 & 498.37 & 13 \\
\hline Perm Krai & 15.5 & 367.09 & 25 \\
\hline Samara Oblast & 14.2 & 358.64 & 27 \\
\hline
\end{tabular}

The future of the global economy is associated with the decrease in need of mineral resources in exchange for alternative energy sources. According to experts in oil and gas industry, exhaustion of certain mineral resources is not so far ahead, technical complexity and cost of field development increasing. These factors make the issue of the RF of resource regions development number one priority.

Strategy of economic development of the Russian Federation is aimed at well-balanced social-economic development of its regions. However, federal documents not always take into consideration specific features of a region's economy. Each administrative regional body creates development strategies individually. Regional documents set the goals and identify priority areas, but do not substantiate the mechanism for achieving these goals. Raw areas have not yet become centers of innovative development, only declaring their intention to diversify regional economy. Further development of these regions require significant transformations, which will affect not only the production and mineral extraction, but also the employment system, infrastructure development and other aspects. Thus, the RF regional policy should focus on the issues of prospective development of raw regions, considering external and internal environment. The raw areas should reorient their development strategies at "non-resource" future.

Initial step for creation of new development strategies for a region is modeling of its social-economic development. This approach allows determining the degree of dependence between parameters, which form the resulting indicators for different industries, such as investments and GRP. The purpose of this article is to develop the methodology for assessing the impact of different performance indicators of different industries on Gross Regional Product (GRP).

\section{DATA AND METHODS}

In Russia, calculation of regional indicators is based on the methodology of the national accounting. Generalizing indicator that shows the development of the region is GRP. Information base for the research is the data taken from the Federal State Statistics Service.

This methodology contains several steps. The first step is the structural GRP analysis and the identification of each industry contribution. 
The second step is the construction of the equation that demonstrates how a resulting factor of each industry depends on key factors. So, we mean the production function, which shows the dependence of output on the resources, used in the process. The amount of the resources, used for production or their prices is production factors. The production function shows the best possible variant, where the resources are used in the most efficient way. It is a one-valued deterministic function (not stochastic). The fact of dependency of output $\mathrm{y}$ on production factors $\mathrm{x}$ is formalized by the following equation (1):

$$
y=f(x)
$$

where $\mathrm{x}=\operatorname{col}\left\{\mathrm{x} 1, \ldots, \mathrm{x}_{\mathrm{n}}\right\}, \mathrm{x}_{\mathrm{i}}$ is a quantity or price of resources used for the production of each i-type.

In the methodology, the following factors are used:

$\mathrm{x}_{1}$ - investments into fixed assets (set of costs, oriented on buying or recreating fixed assets of companies in the industry);

$\mathrm{x}_{2}-$ total price of fixed assets (full accounting cost);

$\mathrm{x}_{3}$ - number of people, employed in the industry.

To define the dependence between the resulting indicator and production factors for different industries, we have built linear equations (2) with the usage of software package Gretl, used for econometric analysis [4].

$$
y_{n}=b+a_{1} \times x_{1}+a_{2} \times x_{2}+a_{3} \times x_{3}
$$

where $y_{n}$ is the dependent variable (output of the industry) in monetary terms; $b$ is an absolute term; $a_{1,2,3}-$ regression coefficients.

Regression coefficients represent the dependence of the dependent variable on the production factor without showing the influence of other factors.

Gretl automatically calculates criteria and coefficients of quality, presenting the accuracy of the constructed equations. One of them is the coefficient of determination (R-square), which is a number indicating the proportion of the variance in the dependent variable that is predictable from the independent variable. It can range from 0 to 1 : the closer to 1, the better is the overall quality of the model. This coefficient is often considered the main indicator for assessing the quality of the model.

The third step is to assess the quality of the model and interpret the results.

\section{RESULTS}

The research takes the case for Tyumen Oblast. The contribution of this region's economic development of the Russian Federation is essential and, thus, its assessment was chosen for the method demonstration. The contribution of Tyumen Oblast to economic indicators of the RF is presented in Table 3.

Table 3 - The contribution of Tyumen Oblast to economic indicators of RF 


\begin{tabular}{lc}
\hline Population & 2,5 \\
\hline Average number of people employed in the economy & 2,9 \\
\hline Gross regional product (in percent of GDP) & 8,8 \\
\hline Fixed assets & 12,7 \\
\hline Production output of mining & 37,8 \\
\hline Production output of manufacturing & 4,0 \\
\hline
\end{tabular}

Figure 2 demonstrates the structure of Tyumen Oblast GRP [5]

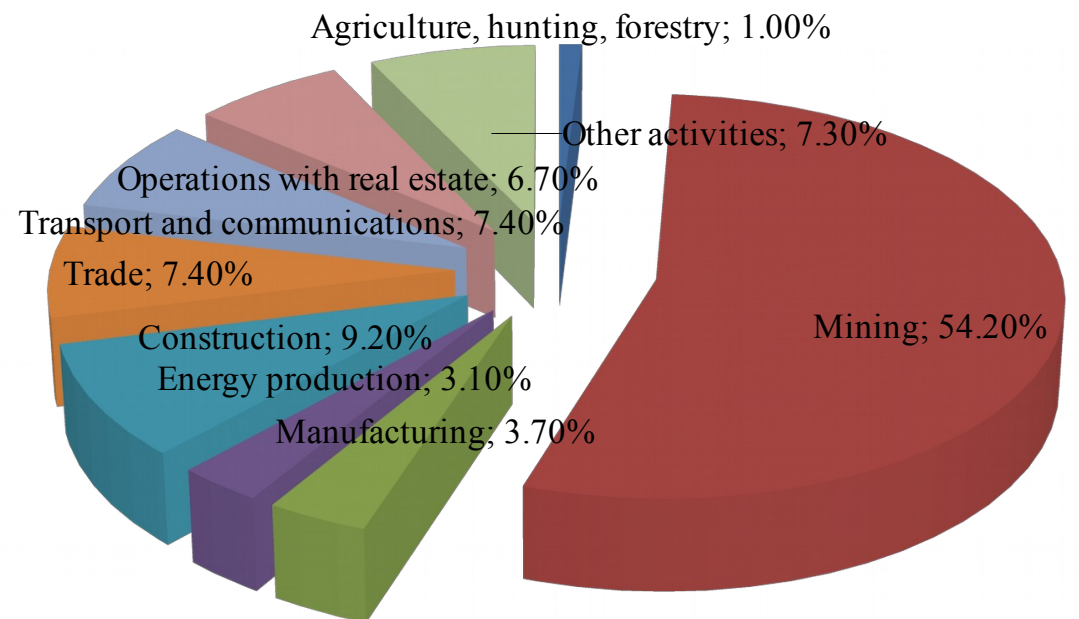

Figure 2 - The structure of Tyumen Oblast GRP, 2015

The calculations of the parameters for the multiple regression equation for industries of Tyumen Oblast are represented in Table 4. The regression coefficients have different units of measure, which make them incomparable, so it is hard to assess their impact on the dependent variable. To make them comparable, all variables in the equation are expressed in shares of standard deviations, in other words, standardized regression coefficients are used.

Table 4 - The regression equations of dependence between Tyumen Oblast industries output and investments in fixed assets, volume of fixed assets, number of people employed in the industry

\begin{tabular}{lcc}
\hline \multicolumn{1}{c}{ Industry } & Regression equations & $\mathrm{R}^{2}$ parameter \\
\hline Mining & $\mathrm{Y}=6432052+5.06 \mathrm{X}_{1}+0.19 \mathrm{X}_{2}-5356.53 \mathrm{X}_{3}$ & 0.99 \\
\hline Construction & $\mathrm{Y}=-38766.31+1.66 \mathrm{X}_{1}+2.72 \mathrm{X}_{2}+31.70 \mathrm{X}_{3}$ & 0.98 \\
\hline $\begin{array}{l}\text { Agriculture. } \\
\text { Hunting. forestry }\end{array}$ & $\mathrm{Y}=7956.37+1.06 \mathrm{X}_{1}+1 \mathrm{X}_{2}-44.06 \mathrm{X}_{3}$ & 0.98 \\
\hline Manufacturing & $\mathrm{Y}=-72827.67+1.18 \mathrm{X}_{1}+4.83 \mathrm{X}_{2}+1088.29 \mathrm{X}_{3}$ & 0.87 \\
\hline
\end{tabular}




\begin{tabular}{lcc}
\hline Trade & $\mathrm{Y}=-96283.3+69.86 \mathrm{X}_{1}+3.03 \mathrm{X}_{2}+1452.22 \mathrm{X}_{3}$ & 0.94 \\
\hline $\begin{array}{l}\text { Production of } \\
\text { energy }\end{array}$ & $\mathrm{Y}=-110576.4+1.16 \mathrm{X}_{1}+0.35 \mathrm{X}_{2}+230.96 \mathrm{X}_{3}$ & 0.95 \\
\hline $\begin{array}{l}\text { Transport and } \\
\text { communications }\end{array}$ & $\mathrm{Y}=332700.89+0.64 \mathrm{X}_{1}-0.012 \mathrm{X}_{2}-3788.18 \mathrm{X}_{3}$ & 0.99 \\
\hline
\end{tabular}

\section{CONCLUSION}

The analysis allows determining the degree of industrial output dependence on the investments made in various industries, which has an impact on the Gross Regional Product. The case for Tyumen Oblast is described in details, as the investment factor in the region has the most significant impact on retail and mineral extraction development. The distributed lag model can be used for more precise assessment of the impact of the investment factor. However, the authors have concluded that the proposed method can be successfully employed to calculate the investment/industrial output dependences, thus contributing to strategic planning, which makes an inseparable part of regional economic policy regarding the structure and effectiveness of investments, especially under the circumstances of high investment activity.

\section{REFERENCES}

[1] Export and import of the Russian Federation/Federal State Statistic Service. Accessmode:http:/www.gks.ru/wps/wcm/connect/rosstat_main/rosstat/en/figures/ activtties/ (in Russian)

[2] Key World Energy Statistics/International Energy Agency. Access mode: https://www.iea.org/publications/freepublications/publication/key-world-energystatistics.html (in Russian)

[3] Main indicators of mining and quarrying, manufacturing, electricity, gas and water supply/Federal State Statistic Service. Access mode: http://www.gks.ru/wps/wcm/connect/rosstat_main/rosstat/en/figures/industry/_in Russian)

[4] GNU Regression, Econometrics and Time-series Library «Gretl». Access mode: http://gretl.sourceforge.net (in Russian)

[5] Tyumen Oblast in figures 2016/State Statistic Service of Tyumen Oblast. Access mode: http://tumstat.gks.ru (in Russian) 
